\title{
Enhancement Of Labor Productivity Through Performance Assessment At Hotel Garuda Plaza, Hotel Madani, And Hotel Novotel Soechi International Medan
}

Onan M. Siregar, Maulidina, FahmiSulaiman

Faculty of Social and Political Science, University Of Sumatera Utara

Business Administration Program, Polytechnic LP3I Medan

Industrial Engineering Program, Polytechnic LP3I Medan

Email: onan@usu.ac.id

\begin{abstract}
Performance improvements are desirable from both employers and workers. Employers want employee performance both for the benefit of increased work and corporate profits. On the other hand, workers are concerned for self - development and job promotion. It can be said that a good employee performance aimed to increase productivity. Therefore, the role of performance evaluation is very influential in the productivity of employees in the company for the system improvement work done by each component in the company. National board certification profession ( BNSP ) allocate 1,000 the professional certification hotels and restaurants in north sumatra .However, the quota of ' subsidy' the government is nowhere to be used, because the Association of Indonesian Hotels and Restaurants ( PHRI) North Sumatra has avacuum.In fact, the professional certification for employees hotels and restaurants get important point operating in the era of ASEAN economic community that began December 2015. " from thousands of employees hotels and restaurants in north sumatra, only 200-an certified.
\end{abstract}

Keywords: Performance Appraisal, Performance, Productivity

\section{INTRODUCTION}

Improved performance is desirable either for the employer and workers.The employer wants employees good performance for the benefit of increased working results and corporate profits.On the other hand, the workers concerned for self-improvement and promotion work. It can be said that the performance of a good employee aims to improve productivity.Hence, a role in a major influence in productivity performance evaluation of an employee in enterprises to for the repair of theworking system done by each necessary component in the company. For that purpose will management system needed a good performance. For these purposes will require a good performance management system.Nurholis ( 2010 ) in the title influence the implementation of the assessment of work productivity workers in call center PT.Telkomsel Medan said that " productivity workers in call center PT.Telkomsel Medan caused by the implementation of the assessment, the rest are affected by another variable as the emotional intelligence,incentives/bonus,allowance,health,th e status of employees,occupational safety and others". However, the government ' subsidy' this could not be used, because the Association ofIndonesian Hotels andRestaurants (PHRI ) North Sumatra hasavacuum.While, profession certificates for employees hotels and restaurants a requirement absolute operating in the ASEAN economic community that began December 2015. " from thousands of hotel employees and restaurant in north sumatra, only 200 certified.While, October, at least $50 \%$ of hotel employees starred 2 and 3 have to professional certified. If not the license and his hotel restaurant can revoke, ' said thehead of regional forum( MUSDA )PHRI of North Sumatera ,JaparLGultom when they have anaudience with the council speaker north sumatra,Ajib Shah,Tuesday ( 31 / 3 / 2015 ).

Accompanied by secretaryof regional forum (MUSDA), Ginting Eva, vice chairman of PHRI North Sumatera Denny S. Wardana, the area coordinator management PHRINorth SumateraRica F Syam would leave and deputy secretary, Prana Hutabarat stated that one of regional forum (MUSDA)PHRI North Sumatera agenda to save the hotel industry in north sumatera.For,about300 hotel in north sumatera, still, one who was taking care of business certification.There are a thousand a ', but not for its container distributed ( $P H R I)$ North Sumateravacuum for eight years, he said .'Eva Gintingsaid,regional forum (MUSDA)PHRI North Sumateradate which was held on april10-11, expected to theselection of that can increase the hotel industry and restaurant in north sumatra.Also, be a medium for the hotel and restaurant, related to various government policy.As known, the government has issued law no 10the year 2009 about tourism and 
government regulation no 52 years 2012 business and certification of certification competence in the field of tourism.Also, the Minister of Administrative Reform and Bureaucratic Reform (PAN-RB) issued Circular Letter (SE) Number 11 of 2014 on Restrictions on Outer Meeting / Meeting Activities. He said the impact of Circular Letter(SE)Menpan-RB resulted in the hotel industry market share declined by 40 percent, even some hotels have 'lay off' or lay off 30 percent of its employees. "The chairman of PHRINorth Sumatera which is elected later is expected to be able to bridge the hospitality entrepreneurs with various government policies," he said.

Chairman of Parliament SumutAjib Shah accompanied by Chairman of Commission C (Finance) DPRD North Sumatra MuchridNasution welcomed and positive steps to reactivate PHRI North Sumatra. "We are confident that PHRI will contribute to the development of North Sumatra, promote not only industry but also build its workers," Ajib Shah said. Initially, H.Ajib Shah was surprised to hear the statement that within the past 8 years the Association of Hotels and Restaurants Indonesia (PHRI) of North Sumatra does not work.Though the government is very hopeful of the existence of this organization to increase local revenue. As stated by Ajib Shah, from the government side, the existence of PHRI is needed to build North Sumatra. Therefore, the role of PHRI organizations engaged in the tourism sector is very strategic in helping to increase the economy of the community. Most importantly, PHRI can contribute to preserving the environment and promoting various tourism objects in North Sumatra. "Lake Toba is a great grace and an icon of North Sumatra, and a beautiful tourist attraction Brastagi.We hope PHRI able to maintain the environment and promote various attractions in the province of North Sumatra," pleaded Ajib Shah. Based on the background described above, the researcher is interested in conducting research "ENHANCEMENT OF LABOR PRODUCTIVITY THROUGH PERFORMANCE ASSESSMENT AT HOTEL GARUDA PLAZA, HOTEL MADANI, AND HOTEL NOVOTEL SOECHI INTERNATIONAL MEDAN."

The problem formulation that authors pointed out in this study is: (1) How the performance appraisal methods applied Hotel Garuda Plaza, Hotel Madani, and Hotel Soechi International. (2) How does the performance appraisal impact on employee productivity Hotel Garuda Plaza, Hotel Madani, and Hotel Soechilnternational. (3) What performance appraisal indicators affect the employee productivity of Garuda Plaza Hotel, Hotel Madani, and Hotel SoechiInternational.

To clarify and to restrict the scope problem with the purpose of produce a systematic description hence writers feel need to make restrictions problems that are employees at company garuda plaza hotel, civil hotel, and hotels soechi international have not changed management during the visit.Variable-variable this research is assessed performance and productivity.Indicators research to variable performance assessment is quantity work, the quality of work, the process, time, discipline, loyalty, and cooperation.While indicators research for variables productivity s a skill and initiative.

As for writer research, this is a (1) analyze performance assessment method used garuda plaza hotel, civil hotel, and hotels soechi international.(2) analyze the influence of assessing performance against productivity garuda plaza hotel employees, civil hotel, and hotels soechi international.(3) to identify indicators performance assessment that influencesproductivity garuda plaza hotel employees, civil hotel, and hotels soechi international.

The benefit of research who writers minutely between for another garuda plaza hotel, civil hotel, and hotels soechi international be able to improve the performance of employees all fronts which are with the hotels.

\section{MATERIALS AND METHODS}

A.Place and time research

The research was conducted at Garuda Plaza Hotel Medan, Hotel MadaniMedan, and NovotelSoechi International Hotel Medan. The study period was conducted from February 2015 to May 2015.

\section{B.Data collection}

Data is one component watercourse to a study.Moreover, so to help the research phase used technique data collection.According to sunyoto (2013: 63 ) stage data collection consist of ( 1 ) observation the field is data collection by means of observations directly against the 
condition and the state of system penggajian in companies that subject to research so that it can be found the fact or reality required in report this report.( 2 ) interview is the process of receive explanation for research purposes by means of question and answer, while face to face between the questioner or interviewer with the answering or the respondents with menggunakann instrument called the interview guide ( an interview guide ).( 3 ) study documentation is data collection that studies documents, other books, or various articles derived from hotel garuda plaza medan, civil hotel medan and hotel novotel soechi international medan.

\section{C.Data type}

The types of data on in this research was primary data, namely the data obtained through research directly to object research which has yet to be processed writer, of the results of the questionnaire to an employee hotel garuda plaza median, civil hotel medan and hotel novotel soechi international medan and interviews with hrd about performance evaluation of implemented company.

\section{D.Population}

According toSugiyono(2009: 115) that "Population is a generalization region consisting

\begin{tabular}{|c|l|l|c|}
\hline $\begin{array}{c}\text { Rese } \\
\text { arch } \\
\text { varia } \\
\text { ble }\end{array}$ & Defenition & \multicolumn{1}{|c|}{ Indicator } & $\begin{array}{c}\text { Sc } \\
\text { al } \\
\text { e }\end{array}$ \\
\hline $\begin{array}{c}\text { Perfo } \\
\text { rman } \\
\text { ce } \\
\text { appra } \\
\text { isal } \\
\text { compare to to } \\
\text { those standards } \\
\text { of employee } \\
\text { performance } \\
\text { which have } \\
\text { been } \\
\text { determined. }\end{array}$ & $\begin{array}{l}\text { 1. The quantity } \\
\text { work } \\
\text { 2. The quality of } \\
\text { 3. Process } \\
\text { 4. Time } \\
\text { 5. Discipline } \\
\text { 6.Loyalty } \\
\text { 7.Team work }\end{array}$ & \\
\hline $\begin{array}{c}\text { Produ } \\
\text { ctivity } \\
\text { emplo } \\
\text { yees }\end{array}$ & $\begin{array}{l}\text { Is the contrast } \\
\text { between the } \\
\text { human with of } \\
\text { resources in any } \\
\text { given period }\end{array}$ & 1.Skill \\
2.Initiative & ert \\
\hline
\end{tabular}

of objects/subjects that have certain qualities and characteristics set by the researcher to be studied and then in draw conclusion."
Based on the above explanation, then the population in this study are all employees of Garuda Plaza Hotel Medan, Hotel MadaniMedan, and Hotel NovotelSoechi International Medan.

\section{E.Sample}

According Sunyoto (2013: 15) that "Sample is part of the number and characteristics possessed by the population." The following is described the calculation of sampling based on the formula stratified random sampling.

$$
\begin{aligned}
& \mathrm{n}=\frac{\mathrm{N}}{1+\mathrm{Ne}^{2}} \\
& \mathrm{n}=\frac{300}{1+\{300(0.05)} \\
& =171,429 \\
& =\quad 172 \text { people }
\end{aligned}
$$

\section{Description :}

samples

$\mathrm{N}=$ The number of research

$\mathrm{N}=$ A population of the sum total garuda plaza hotel employees medan ,civil hotel medan and hotel novotelsoechi international medan.

$\mathrm{E}=$ = leniency inaccuracy due to intolerable sampling error (researcher using e 0.05).

F.Operational definition

Definition operational used to give a definition to a variable using giving the meaning of, or specify activities or gave an operationalnecessary for measuring variable the.The following operational definition of the indicators used.

\section{G.Data collection method}

Data collection method used in this research is a technique the collection of primary data, which are (1) the method of theinterview ( 2 ) the questionary( 3 ) observation.

\section{RESULT AND DISCUSSION}

Madani hotel, Garuda Plaza hotel, and hotels Soechi International assessed any 
performance in six months. Thishad the aim that company can take action corrective quickly against a fault or lack of employees,efficiently do not take up the time the supervisor ), and costeffective.Performance assessment method used is rating scale.Assess performance done by the leader of .Performance evaluation of power roomy performed at some stage. At first, theassessment was done by coordinator the court for the field coordinator for were the ones who most know work daily power roomy.After that, the assessment results of the will be submitted to staff for evaluation. If has been completed evaluated, the assessment results of the performance submitted to the to follow them up.Leaders call each employee who had already been assessed its performance to show the assessment results of the performance.

\section{ConCLuSION}

The results of the above research than in conclusion that the three hotels perform performance appraisal every six months. It has a purpose so that companies can take corrective action quickly against employee error or shortage, efficient (not atimeconsumingsupervisor), and cost-effective. Performance appraisal method used is rating scale. Performance appraisal conducted by the leadership. Field performance assessment conducted in several stages. Initially, the assessment was carried out by the field coordinator because the field coordinator was the one most knowledgeable about the daily work of the field staff. After that, the results of the assessment will be submitted to the Staff for evaluation. Once evaluated, performance appraisal results are submitted to the leadership for follow-up. The Leader calls every employee who has been assessed for performance to demonstrate performance appraisal results.

\section{REFERENCE}

Agustina Maarif, Fauzia. 2005. Analisis Hubungan Penilaian Kinerja dengan Produktivitas Karyawan (Studi Kasus pada Sub Divisi Group Liabilities Consumer Banking PT Bank Bukopin, Jakarta) Skripsi pada Departemen Manajemen Fakultas Ekonomi dan Manajemen. Institut Pertanian Bogor, Bogor.

Davis, Tony, Cutt, Maggie, Flynn, Nail, Mowl, Peter, dan Orme, Simon. 2009. Talent Assessment. PPM, Jakarta Pusat.

Dessler, G. 2006. Manajemen Sumber Daya Manusia . Indeks, Jakarta.
Flippo dan Masud. 1996. Manajemen Personalia. Erlangga, Jakarta.

Hasibuan. 2007. Manajemen Sumberdaya Manusia. PT Bumi Aksara, Jakarta.

Iskandar, Andri. 2005. Analisis Pengaruh Penilaian Kinerja Terhadap Produktivitas Kerja Karyawan di Kantor PUSDIKLATWAS BPKP. Tesis pada Program Studi Magister Manajemen Agribisnis. Sekolah Pascasarjana Institut Pertanian Bogor, Bogor.

Kuncoro, Mudrajad. 2003. Metode Riset untuk Bisnis \& Ekonomi. Erlangga, Jakarta.

Mangkuprawira, Sjafri. 2007. Manajemen MutuSumber daya Manusia. Ghalia Indonesia, Bogor.

Nachrowi. 2002. Penggunaan Teknik ekonometri. PT Raja Grafindo Persada, Jakarta.

Nugroho, B. 2005. Strategi Jitu Memilih Metode Statistik Penelitian dengan SPSS. ANDI, Yogyakarta.

Narbuko, C. 2001. Metodologi Penelitian. Bumi Aksara, Jakarta.

Nurholis, Iman. 2010. Pengaruh Pelaks anaan Penilaian Kinerja Terhadap Produktivitas Kerja Karyawan (Studi pada Call Center PT, Telkomsel Medan). Skripsi pada Departemen Ilmu Administrasi Nega ra Fakultas Ilmu Sosial dan Ilmu Politik. Universitas Sumatera Utara, Medan.

P. Siagian, Sondang. 2007. Fungsi-Fungsi Manajerial. PT Bumi Aksara, Jakarta.

P. Siagian, Sondang. 2007. Manajemen Sumber Daya Manusia. PT Bumi Aksara, Jakarta.

P. Siagian, Sondang. 2008. Manajemen Stratejik. PT Bumi Ak sara, Jakarta.

Priyatno, D. 2008. Mandiri Belajar SPSS untuk Analisis Data dan Uji Statistik. MediaKom, Yogyakarta.

Rivai, Veithzal dan Mohd. Basri, Ahmad Fawzi. 2005. Performance Appraisal. PT Raja Grafindo Persada, Jakarta.

Rivai, Veithzal dan Jauvani Sagala, Ella. 2009. Manajemen Sumber Daya Manusia untuk Perusahaan. PT RajaGrafindo Persada, Jakarta.

Simamora, Henry. 2006. Manajemen Sumber Daya Manusia. STIE YKPN, Yogyakarta.

Sinungan, Muchdarsyah. 2008. Produktivitas Apa dan Bagaimana. PT Bumi Aksara, Jakarta.

Siswanto, H.B. 2008. Pengantar Manajemen. PT Bumi Aksara, Jakarta.

Sumarsono, Sonny. 2003. Ekonomi Mana jemen Sumberdaya Manusia \& Ketenagakerjaan. Graha Ilmu, Yogyakarta. 
Tim Penyusun Kamus. 2002. Kamus Besar Bahasa Indonesia. Balai Pustaka, Jakarta.

Tisnawati Sule, Ernie dan Saefullah, Kurniawan. 2008. Pengantar Manajemen. Prenada Media, Jakarta.
Umar, Husein. 2003. Metode Riset Bisnis. PT Gramedia Pustaka Utama, Jakarta.

Walpole, R.E. 1993. Pengantar Statistika. PT. Gramedia Pustaka Utama, Jakarta.

Yuniarsih, Tjutju. 2009. Manajemen Sumberdaya Manusia. Alfabeta, Bandung. 